\title{
SIRKULASI FILM DAN PROGRAM TELEVISI DI ERA DIGITAL STUDI KASUS PRAKTIK DOWNLOAD DAN STREAMING MELALUI SITUS BAJAKAN
}

\author{
Irham Nur Anshari \\ Departemen Ilmu Komunikasi, Universitas Gadjah Mada \\ Email: irham.nur.anshari@ugm.ac.id
}

\begin{abstract}
ABSTRAK
Penelitian ini memaparkan bagaimana sirkulasi film dan program TV melalui situs bajakan, khususnya dari perspektif partisipan. Partisipan dalam hal ini lebih dari sekedar penonton, karena partisipan dalam media baru adalah pihak yang turut mencari, menseleksi, merespon balik, maupun merekomendasikan video digital dalam situs tersebut. Akses partisipan terhadap video digital dimungkinkan melahirkan praktik-praktik baru konsumsi film dan program TV, seperti men-download dan menonton secara streaming. Penelitian ini menggunakan metode studi kasus, dengan berfokus pada praktik partisipan di wilayah Yogyakarta. Pencarian data dilakukan baik melalui observasi pada platform sirkulasi (khususnya situs-situs bajakan) serta focus group discussion pada 6 partisipan. Dari praktik partisipan atau pelaku, setidaknya dapat dicatat beberapa aspek yang melahirkan praktik ini: keintiman pelaku dengan teknologi digital baik yang legal maupun ilegal, semangat mengakses tontonan dengan efisien dan semurah mungkin, serta pertimbanganpertimbangan teknis seperti perihal subtitle dan kualitas video.
\end{abstract}

Kata kunci: film, televisi, video, sirkulasi, pembajakan, streaming, download

\section{A. PENDAHULUAN}

Pada tahun 2015, pemerintah Indonesia melaluiKementrianKomunikasidanInformasi membuat kebijakan untuk memblokir 22 situs yang dianggap mengedarkan film produksi Indonesia secara ilegal. Kebijakan tersebut mendapatkan sambutan baik oleh perwakilan Asosiasi Produser Film Indonesia, Fauzan Zidni, yang melihat bahwa situs bajakan yang ada tersebut membuat jasa distribusi online resmi enggan berinvestasi di Indonesia (Pradesha, 2015). Ironisnya, sistem blokir sebuah situs hanya menyentuh alamat situs tersebut, tidak infrastrukturnya. Situs film bajakan pun hanya berganti alamat dan tetap dapat ditemui oleh para penggunanya.

Dalam observasi awal yang dilakukan peneliti, peneliti menemukan beberapa situs yang masih mensirkulasikan film maupun program TV secara ilegal. Situs $x x 1$.tv misalnya, masih beredar dengan menawarkan berbagai film baik produksi
Indonesia maupun luar negeri yang dapat diakses secara gratis. Tidak hanya film yang merupakan produk primer bioskop, dapat ditemukan situs lain yang mensirkulasikan program TV secara ilegal. Situs dramacool9. io misalnya, menawarkan berbagai program TV, khususnya serial drama Asia.

Persebaran film dan program TV secara ilegal melalui situs bajakan ini nampaknya menjadi tantangan sistem distribusi online film dan program TV yang resmi. Sejak tahun 2007 misalnya, distribusi film dan program TV telah diinisiasi oleh Netflix melalui sistem video-on-demand yang merupakan sinyal perubahan pada lanskap televisi digital (Jenner, 2014). Pada sistem ini, audiens bisa memesan film atau program TV dalam bentuk data digital langsung ke perangkat menonton tanpa melalui medium penyimpanan seperti VCD atau DVD. Sistem video-on-demand ini terus berkembang hingga pada sistem di mana konsumen dapat membayar konten sesuai 
bentuk aksesnya, apakah secara streaming atau download (Kim \& Park, 2008).

Fenomena masih muncul dan bertahannya situs bajakan ini tentunya menuntut pemahaman baru pada bagaimana audiens film dan program TV masih mengakses situs-situs tersebut. Partisipasi audiens terhadap film dan program televisi dalam hal ini perlu dibaca ulang. Partisipan audiens yang sebelumnya dilihat sekedar sebagai penonton, kini meluas pada aktivitas mencari, menseleksi, merespon balik, maupun merekomendasikan video digital dalam situs tersebut. Akses partisipan terhadap video digital dimungkinkan melahirkan praktik-praktik baru, seperti men-download dan menonton secara streaming.

Berdasar rumusan masalah di atas, penelitian ini merumuskan pertanyaan penelitian sebagai berikut: Bagaimana sirkulasi film dan program TV melalui situs bajakan? Sebagai limitasi penelitian, pertanyaan penelitian tersebut dijawab dengan menggunakan perspektif partisipan pengakses situs. Perspektif pihak lain seperti produsen konten (pembuat film dan rumah produksi program televisi) atau pengelola situs bajakan sengaja diabaikan dalam penelitian ini. Secara rinci, penelitian ini bertujuan untuk mendapatkan data terkait tiga hal, yakni:

1. Bagaimana dinamika situs bajakan yang diakses oleh partisipan.

2. Bagaimana partisipan memahami karakteristik situs.

3. Bagaimana praktik partisipan mengakses konten film dan program televisi dari situs tersebut.

Dalam kerangka ilmu komunikasi, hasil dari penelitian ini diharapkan berkontribusi pada perkembangan pemahaman pada tiga konsep terkait media hiburan dan dinamika masyarakat informasi. Pertama, konsep sirkulasi digital, di mana konten media film dan program televisi dalam hal ini tidak lagi didistribusi satu arah dari produsen ke penonton namun tersebar dengan melibatkan banyak aktor. Kedua, konsep mengenai pembajakan digital yang tumbuh seiring perkembangan sirkulasi digital. Terakhir, konsep mengenai perkembangan industri sirkulasi film dan program televisi secara online beserta tantangantantangannya. Analisis dari penelitian ini diharapkan memberikan sumbangan pada pemahaman sirkulasi film dan program televisi di era digital.

Dalam kerangka industri media hiburan, khususunya film dan televisi, penelitian ini diharapkan memberikan pengetahuan dari perspektif "audiens". Hasil penelitian ini dapat menjadi pertimbangan dalam mengevaluasi beberapa sistem "distribusi" yang coba ditawarkan produsen terhadap audiens melalui jalur digital, misalnya sistem video on demand. Penelitian ini juga mencoba memberikan pemahaman baru mengenai isu pembajakan media digital yang melibatkanb berbagai pihak.

Penelitian ini penting dilakukan saat ini untuk memahami secara mendalam bagaimana sirkulasi media, khususnya film dan program televisi, di era digital yang terus berkembang seiring perkembangan teknologi media baru. Sementara bentuk distribusi lama masih berlangsung, baik melalui bioskop maupun saluran televisi, saluran-saluran baru digital melahirkan praktik-praktik baru relasi antara audiens dan produk audio visual.

\section{B. TELAAH PUSTAKA}

\section{Sirkulasi Media di Era Digital}

Dinamika media baru ini membawa persebaran media dalam suatu konsep yang oleh Henry Jenkins dkk. (2013) dalam bukunya Spreadable Media disebut sebagai "sirkulasi'. Seperti halnya "distribusi", sirkulasi merupakan "proses" di antara produksi dan konsumsi. Namun berbeda dengan distribusi yang bersifat top down dan umumnya komersil, sirkulasi merujuk pada penyebaran konten media baik yang top down maupun bottom up serta komersil maupun grassroots. Pergeseran dari distribusi ke sirkulasi memberikan sinyal sebuah gerakan menuju budaya yang lebih 
partisipatif di mana publik bukanlah sekedar konsumen tetapi juga merupakan pihak yang membentuk, membagi, membingkai, atau me-remix konten media dengan caracara yang tidak pernah diimajinasikan sebelumnya (Jenkins dkk., 2013: 2).

Sirkulasi konten ini tidak bisa dipungkiri terkait erat dengan perkembangan teknologi media. Perangkat komunikasi online terus berkembang memfasilitasi praktik sirkulasi yang informal dan makin instan. Platform-platform ini bukan hanya menawarkan pengguna untuk membagi konten, tapi juga mendapatkan pendapatan alternatif dari aktivitasnya. Meski demikian, Jenkins dkk. menolak asumsi bahwa infrastruktur teknologi media merupakan aspek primer dalam dinamika sirkulasi ini. Jenkins dkk. (2013: 63) menggarisbawahi poin penting bahwa sebagian besar dari kita yang tumbuh dalam ekonomi kapitalis memahami praktik membeli dan menjual barang. Meski demikian, kita juga tumbuh dalam tatanan sosial lain yang menuntut adanya sikap saling berbagi. Dalam logika komoditas, berbagi data dapat dilihat merusak secara ekonomi; sementara dalam logika sosial, tidak saling berbagi justru merusak tatanan sosial. Berdasar paparan di atas, tulisan ini bermaksud meninjau praktik mengopi film di warnet dengan kerangka bagaimana sirkulasi film terkait erat dengan teknologi media serta konteks sosial \& budaya para partisipan.

Perkembangan teknologi yang memungkinkan film tidak lagi hanya ditonton di layar lebar gedung bioskop telah menjadi fenomena yang menarik minat para peneliti. Barbara Klinger (2006) dalam bukunya Beyond the Multiplex mendiskusikan praktik menonton film melalui home theater, VHS, DVD, televisi kabel, dan internet). Menggunakan istilah new media aristocrats sebagai konteks lingkup risetnya, Klinger mencatat bagaimana sejak tahun 1990-an home theater telah menjadi tren eksebisi di mana audiens mendesain ruangan menonton beserta perangkat televisi dan audio yang canggih untuk menonton film (Klinger, 2006: 17-53). Meskipun televisi melalui siarannya telah lama menjadi salah satu bentuk eksebisi film di luar bioskop, kemunculan tren home theater secara tegas menunjukkan adanya pergeseran praktik menonton film sebagai aktivitas komunal ke personal.

Dalam salah satu bagian khusus, Klinger (2006: 54-90) juga membahas perkembangan praktik mengoleksi film seiring kemunculan teknologi VHS, laser disc, hingga DVD. Dalam hal ini, pengkoleksian film menciptakan pergeseran praktik menonton sebagai praktik yang temporal (hanya bisa ditonton secara sekali di bioskop, kecuali membayar ulang untuk menonton ulang) dan linear (dari awal hingga selesai secara langsung). Ketika film diakses di perangkat personal seperti DVD player, film dapat ditonton kapanpun dan berkali-kali sesuai kehendak sang kolektor. Film dalam bentuk ini juga dapat di-pause ataupun di-rewind sesuai dengan kehendak penonton.

Perkembangan internet memungkinkan sirkulasi film yang semakin sederhana, cepat, dan bebas biaya. Michael Strangelove (2015: 48-73) mendiskusikan pembajakan televisi dan film dengan menyebut adanya dua bentuk: download dan streaming. Kedua meteode ini menggunakan sistem P2P seperti BitTorrent. Men-download atau mengunduh sebuah film membutuhkan waktu menunggu meskipun film kemudian menjadi dimiliki sehingga bisa diakses di waktu lain, sementara streaming cenderung hanya membutuhkan waktu untuk menunggu film dimulai tetapi penonton tidak menyimpan film tersebut. Menariknya, Strangelove mencatat bagaimana kemunculan platform streaming legal seperti Hulu dan Netflix menurunkan angka pembajakan. Ini menunjukkan bahwa kemudahan akses menjadi faktor penting bagi audiens film dalam lingkup media baru di samping faktor ekonomi.

\section{Pembajakan Media Digital}

Perkembangan teknologi media baru ditandai dengan terkonversinya media analog menjadi digital. Hal ini memungkinkan produk media digital menjadi lebih cepat dan mudah menyebar. 
Sirkulasi produk media digital yang sulit dikontrol ini melahirkan sebuah fenomena yang kerap disebut pembajakan media digital atau lebih singkatnya pembajakan digital. Salah satu definisi umum mengenai pembajakan digital atau digital piracy adalah praktik mengopi (to-copy) dan menjual secara ilegal produk film, musik, software komputer digital, dan media digital lainnya (Anshari, 2017).

Bila dicermati lebih dalam, status "ilegal" yang disandingkan dengan praktik pembajakan digital ini berdasar pada logika sistem hak cipta. Di era di mana konsumen media tumbuh dalam lingkup media baru, menghakimi pembajakan digital sebagai praktik yang ilegal adalah suatu hal yang problematis. Misalnya bila kita menilik argumen Lawrence Lessig (2004: 75) yang menuliskan (dalam terj.):

Ada banyak sekali jenis pembajakan atas materi-materi yang berhak cipta. Yang paling signifikan adalah pembajakan komersial, yaitu pengambilan tanpa izin konten orang lain dalam konteks komersial.... Akan tetapi, sama halnya dengan pembajakan komersial, ada jenis "pengambilan" lain yang terkait secara langsung dengan internet. Pengambilan itu juga tampak sebagai suatu yang salah bagi banyak pihak dan dianggap sebagai sesuatu yang salah (ilegal) di banyak kesempatan. Bagaimanapun juga, sebelum kita menggambarkan pengambilan ini sebagai "pembajakan", sebaiknya kita memahami dahulu sifat dasar dari tindakan ini.

$\begin{array}{ccc}\text { Lessig } & \text { menggunakan } & \text { konsep } \\ \text { "pembajakan" } & \text { (pembajakan }\end{array}$
tanda kutip) untuk menunjukkan bahwa mendefinisikan pembajakan sebagai definisi tunggal adalah sebuah simplifikasi. Meninjau argumen Lessig, jika faktor kunci dari "pembajakan" yang mau diberantas oleh hukum adalah penggunaan yang "merampok" keuntungan si pencipta (2004: 81), ini berarti perlu dipastikan apakah dan seberapa banyak sistem berbagi dalam budaya mengopi menimbulkan kerugian. Memahami ulang pembajakan digital dari berbagai perspektif menjadi penting dilakukan sebelum meng-ilegal-kan praktik tersebut.

Lebih lanjut, Lessig mencontohkan kompleksitas proses file-sharing atau berbagi data yang sulit untuk sematamata dihakimi sebagai pembajakan dalam pengertian yang salah dan ilegal. la mengkategorikan proses ini ke dalam empat tipe: Pertama, berbagi data sebagai pengganti membeli konten. Kedua, berbagi data untuk "mencicipi" karya tertentu sebelum membelinya. Ketiga, berbagi data untuk mendapatkan akses konten berhak cipta yang sudah tidak lagi dijual. Keempat, berbagi data materi yang tidak berhak cipta atau pemilik hak ciptanya ingin memberikannya secara gratis (2004: 82).

Berdasar paparan di atas, dalam satu dua kasus bisa disepakati bahwa pembajakan digital yang merugikan produsen media secara ekonomi. Namun, di sisi lain perlu adanya pemahaman baru mengenai pembajakan yang mencurigai bagaimana pembajakan dapat juga menguntungkan produsen media. Menghakimi sebuah pembajakan sebagai aktivitas ilegal yang melanggar hukum adalah sebuah perspektif sempit yang dibangun dari perspektif industri dengan logika distribusi konvensional. Perspektif ini menutup mata dari adanya negosiasi pelaku pembajakan yang terus berkembang seiring perkembangan ekonomi dan teknologi distribusi media.

\section{Sirkulasi Film dan Program TV Online}

Riset mengenai sirkulasi video (baik film maupun program TV) telah banyak dilakukan seiring perkembangan industri. Jenner (2016) misalnya mencatat bagaimana sistem distribusi seperti Netflix telah menumbuhkan model praktik menonton yang individualis di mana penonton dapat mengatur jadwal tontonannya. Sementara Kim \& Park (2008) meneliti bagaimana program-program TV di Korea Selatan menawarkan sistem videoon-demand (VOD) setelah pemutarannya di televisi. Menurut Kim \& Park, sistem 
VOD ini mendapkan ketertarikan dari kelompok penonton yang memilih medium menonton sesuai dengan aksesbilitas dan kebiasaannya, dalam hal ini menonton secara online di laptop, komputer, atau ponsel.

Seperti halnya yang dialami oleh industri media hiburan berbasis VCD atau DVD, sistem distribusi online juga mendapatkan tantangan dari praktik pembajakan digital. Kelly Hu (2005) yang meneliti konsumsi drama TV Jepang di Cina menemukan bagaimana fans drama TV Jepang di Cina merupakan pihak yang bergerilya secara otonom, mengembangkan jejaring teknologi digital yang minim biaya, serta menentang hierarki distribusi resmi. Sementara Newman (2012) lebih berfokus pada bagaimana sistem berbagai online program TV yang dimungkinkan oleh infrastruktur database digital online, seperti BitTorrent. Newman mencatat fenomena ini melahirkan pengalaman baru menonton yang kosmopolitan, pergeseran dari TV sebagai media lokal ke global. Perihal BitTorrent ini juga dicatat oleh MacNeil (2016) yang memaparkan bagaimana para pelaku pembajakan digital ini menolak dipandang sebagai kriminal, sehingga perlu didefinisikan ulang makna dari apa yang disebut sebagai praktik ilegal.

Perlu diperhatikan pula bagaimana munculnya sistem distribusi film dan program TV online juga sejalan dengan kultur baru audiens berinteraksi dengan media hiburan. Jung \& Shim (2014) mencatat bagaimana di Indonesia, media online merupakan pilihan utama bagiamana mengkonsumsi dan mensirkulasikan media populer. Hal ini sejalandengan perubahan gaya hidup kaum muda Indonesia generasi digital. Dalam hal ini penting untuk memeriksa bagaimana interaksi partisipan dengan media, baik misalnya melalui praktik streaming di mana menonton perlu terkoneksi oleh internet, atau praktik download di mana penonton perlu menyimpan terlebih dahulu data untuk dapat diakses kemudian.

\section{METODE PENELITIAN}

Penelitian ini menggunakan paradigma konstruktivis atau interpretatif. Paradigma interpretatif digunakan dalam penelitian ini sesuai tujuan untuk memahami bagaimana informan di dalam kondisi mereka seharihari memaknai dan menginterpretasi praktik/peristiwa di dalam kehidupan mereka (Wimmer \& Dominick, 2010). Peneliti dalam paradigma ini berperan sebagai fasilitator atau "penyambung lidah" dari berbagai pandangan yang mampu merekonstruksi pemahaman awal peneliti maupun partisipan.

Dengan pendekatan metode kualitatif, metode penelitian spesifik yang digunakan dalam penelitian ini adalah metode studi kasus. Studi kasus dipilih karena merupakan sebuah metode empiris yang menggunakan berbagai sumber atau data untuk menginvestigasi sebuah fenomena kontemporer (Yin, 2003). Teknik pengumpulan data yang dilakukan terdiri dari: observasi platform online dan FGD.

Dengan berfokus pada praktik partisipan di wilayah Yogyakarta, penelitian ini memilih subjek sebanyak 6 partisipan pengakses situs film atau program TV bajakan yang berdomisili di wilayah Yogyakarta. Pemilihan partisipan dilakukan dengan mempertimbangkan variasi latar belakang partisipan (umur, jenis kelamin, latar pendidikan, dan lain-lain). Penelitian ini menggunakan teknik sampling maximum variation (Lindlof, 2002) yang mengutamakan keberagaman informan untuk memberikan perspektif yang luas dan sevariasi mungkin.

Data yang diperoleh dianalisis menggunakan pattern-matching strategy (Yin, 2003), di mana pola-pola temuan empiris dikomparasi dengan pola-pola yang terprediksi. Pola-pola yang terprediksi ini diperoleh pada tahap persiapan penelitian dengan berbasis pada pencarian informasi terkait serta observasi awal pada situs bajakan. 


\section{HASIL DAN PEMBAHASAN}

\section{Hasil Obervasi Platform Online}

a. Platform Legal

Sebelum memaparkan bagaimana informan melakukan praktik download dan streaming, pada bagian ini dipaparkan terlebih dahulu hasil observasi pada platform-platform online yang memungkinkan sirkulasi produk film dan televisi berlangsung. Observasi dilakukan para beberapa platform dengan membagi karakteristik platfom ke dalam dua jenis: legal dan ilegal. Meskipun riset ini berfokus pada platform ilegal (khususnya situs penyedia film dan/atau program TV bajakan), pemahaman pada platform legal menjadi penting untuk mendapatkan konteks yang luas.

Platform legal dalam hal ini merujuk pada platform yang mensirkulasikan produk film dan/atau televisi dengan sistem kontrak ekonomi yang diketahui oleh produsen. Sistem ini diasumsikan menjadi alternatif bagi produsen dalam mensirkulasikan produk di samping jalur mainstream: film via bioskop, program TV via stasiun televisi. Platform ilegal mengacu pada platform yang mensirkulasikan produk di luar pengetahuan atau kontrak resmi dengan produsen. Dalam hal ini diasumsikan produsen tidak mendapatkan keuntungan ekonomi langsung dari sirkulasi tersebut. Untuk platform legal, ada beberapa platform yang diobservasi, yakni: Google Play TV \& Movie, Netflix, Iflix, UseeTV Go, HOOQ, dan Genflix. Dalam daftar tersebut, sebagaian besar platform menyajikan produk baik film maupun program TV.

Google Play TV \& Movie merupakan platform yang tersinkronisasi dengan akun Google yang dimiliki seseorang. Platform ini umumnya diakses melalui aplikasi Playstore pada ponsel. Pengakses Google Play TV \& Movie akan ditawarkan berbagai fitur, misal: film/ program TV rekomendasi, film/program
TV terbaru, film/program TV yang hanya bisa di-download, tidak dapat ditonton secara streaming. Untuk menu film, akan disajikan informasi berupa: trailer, tahun, durasi, rating, serta judul. Ada pula deskripsi singkat seperti sinopsis, pemain, dan kru film. Di bagian bawah, ada informasi tambahan seperti audio languange, caption, info card, rental expirations, dan how to play. Terkait sistem akses, konsumen diberi pilihan: sewa atau beli serta format SD atau HD (High definition).

Akses streaming film/TV dilakukan dengan memilih fitur sewa. Dalam hal ini konsumen dapat menyewa film/ TV layaknya melalui persewaan DVD film/TV. Waktu sewa akan berakahir sesuai ketentuan: "Rental expires in 30 days or 48 hours after begin playback." Akses download film/TV dapat dilakukan dengan membeli dan men-download produk pada ponsel atau tablet, khususnya jenis ponsel Android, iPhone, dan iPad. Produk hanya bisa didownload di PC/desktop/ laptop dengan menggunakan software Chromebooks. Google Play tidak menggunakan sistem pemasukan dari iklan. Sistem ekonomi yang digunakan hanyalah biaya beli dan sewa dengan range harga sewa sekitar Rp. 19.000 Rp. 25.000. Sedangkan range harga beli bervariasi, dari Rp. 79.000 - Rp. 290.000.

Berbeda dengan Google Play TV \& Movies, iflix merupakan layanan videoon-demand online berbasis langganan, di mana pelanggannya bisa memilih sendiri film atau acara TV untuk ditonton. Layanan ini menawarkan berbagai film dan acara TV populer, baik dari barat, seperti film Hollywood, maupun Asia, seperti drama Korea. Iflix saat ini tersedia di berbagai negara termasuk Indonesia. Iflix dapat diakses via PC/Mac dengan mengakses situsnya secara langsung di www.iflix.com atau via Android dengan menginstall aplikasinya terlebih dulu.

Pengguna iflix dapat mengulang streaming film sesuai dengan menit 
terakhir ia menonton film. Penonton dapat memilih tiga subtitle yang disediakan: English, Indo, Malay. Terkait kualitas video, pengguna tidak diberi keleluasaan untuk memilih kualitas video yang ditayangkan, karena kualitas video sudah diset sekitar 720p atau 480p, menyerupai kualitas DVD. Produk dalam iflix tidak bisa di-download via PC/Mac, hanya bisa di-save di Android, lewat apps Iflix sendiri dengan durasi waktu tertentu, tidak permanen. Seperti halnya Google Play, iflix tidak memuat iklan. Biaya berlangganan iflix sebesar Rp39.000 per bulan.

Perlu dicatat bahwa iflix tidak memiliki kelengkapan dan kecapatan update produk seperti Google Play. Hal ini diasumsikan tergantung bagaimana kerja sama produsen film dengan iflix. Iflix kerap menawarkan justru film-film lama dengan bungkus "marathon pack". Dalam konteks film Indonesia, iflix juga menyajikan film Indonesia lawas seperti film Benyamin dan Warkop DKI.

Sedikit menyerupai iflix, Netflix merupakan layanan video on demand atau membayar langganan secara bulanan tanpa batasan serial tv/film yang dapat diakses. Telah berkembagn di Indonesia sejak Januari 2016 dengan koleksi lebih dari 65.000 judul film dan serial televisi yang bisa ditonton menggunakan TV, laptop, serta perangkat smartphone dan tablet via aplikasinya yang dapat diunduh di Google Play dan App Store. Untuk pasar Indonesia, ada tiga jenis layanan Netflix yang bisa dinikmati. Layanan tersebut adalah Basic, Standard, dan Premium. Perbedaan antara tiap paket terletak pada resolusi gambar film dan jumlah perangkat yang bisa digunakan lewat sebuah akun Netflix secara bersamaan. Pada dasarnya Netflix telah memiliki izin untuk menayangkan fim dan serial TV dari berbagai negara. Tapi izinnya punya keterbatasan wilayah. Jadi ada beberapa konten yang tidak bisa ditayangkan di Indonesia. Kualitas video (film/series) yang bisa di-streaming sesuai dengan paket membership yang diambil, mulai dari kualitas 480p, 720p. 1080p. dan 4K. Biaya berlangganga mulai dari Rp 109.000 per bulan (basic), 139.000 per bulan (standart), 169.000 per bulan (premium).

Platform ini dapat dikatakan paling lengkap dan update dibandingkan iflix dan $\mathrm{HOOQ}$, Netflix paling update. Mereka bahkan memproduksi film dan serial mereka sendiri (Netflix Series) yang tidak dapat diakses via platform lain. Meski demikian, platform ini tidak menawarkan fitur download sama sekali.

HOOQ adalah layanan video on demand yang berasal dr Singapura dan telah beroperasi di Indonesia sejak April 2016. Sebelum beroperasi di Indonesia, HOOQ telah terlebih dahulu melayani pengguna di Filipina, Thailand, dan India. HOOQ tidak membedakan konten yang bisa diakses di tiap-tiap negara, seperti yang dilakukan Netflix. HOOQ membagi kualitas streaming di layanan mereka menjadi tiga kategori, yaitu High, Medium, dan Low. Apabila memilih kualitas High, user akan bisa menikmati video dengan kualitas HD. Jika user menggunakan jaringan internet yang kurang baik, maka secara otomatis $\mathrm{HOOO}$ akan menurunkan kualitas streaming mereka.

Dengan berlangganan layanan $\mathrm{HOOQ}$, user bisa membagi akses yang dimiliki ke lima perangkat. Namun $\mathrm{HOOO}$ hanya mengizinkan user untuk melakukan streaming secara bersamaan dari dua perangkat saja. Beberapa perangkat yang bisa digunakan untuk mengakses layanan Hooq adalah PC, smartphone, tablet, set-top box, dan Smart TV melalui Chromecast. HOOQ juga memiliki layanan wish-list (untuk menonton di masa depan) dan layanan fremium yang memungkinkan pelanggan $\mathrm{HOOO}$ untuk bisa menikmati siaran televisi lokal seperti Kompas TV, RTV, Metro TV, JAK TV, RCTI, MNCTV dan Global TV kapan dan di mana saja secara langsung.Pelanggan 
HOOQ dikenakan biaya Rp 49.500 untuk berlangganan setiap bulannya atau Rp18.700 per minggu dan/atau skema lain, seperti skema akses film-film terbaru Rp. 22,400 per film.

b. Platform llegal

Berbeda dengan platform legal, platform ilegal cenderung tidak bernama resmi. Alamat resmi situs mereka pun dapat berubah-ubah, mensiasati sistem blokir yang ada. Beberapa platform/situs bajakan yang diobservasi dalam penelitian ini yaitu indoXXI, icinema3satu, SevenTorrents, serta Archivemovies.

Indo XXI merupakan Situs online streaming film, serial TV, TV online, dan anime dengan tagline "Nonton Film Online Bioskop Online Terlengkap". Sudah berganti domain beberapa kali, dan dulu sempat dikenal dengan "lk21" atau layar kaca 21 . Koleksi filmnya sendiri kurang lebih sebanyak 1600 buah dan terus bertambah, koleksi program TV (termasuk anime) sekitar 8700 judul dan terus bertambah. Informasi film di situs ini terdiri dari rating, yaitu berpatokan pada ImdB (internet movies database), tanggal rilis, pemain, durasi, kualitas video, dan sinopsis singkat-yang dari tata bahasanya kelihatan kalau pake google translate. Untuk identitas film, seperti aktor, sutradara, negara pembuat, juga berbasis data dari IMdB.

Situs ini menyediakan opsi streaming secara langsung (seperti youtube) dan dengan bantuan 3 apps berbeda. Pertama ada apps add-on/ extension Vidplay untuk browser Chrome, Vidplay untuk Firefox, dan apps IndoXXI untuk Android. Selain itu, user bisa memilih ingin menonton film dalam kualitas 360p, 720p, 1080p (full HD), atau 4K (kualitas yang dapat dipilih tergantung ketersediaan kualitas video yang ditawarkan, karena bisa saja ada film/TV series/anime yang hanya menawarkan satu kualitas saja). Selain itu user juga diberi kebebasan ingin menonton film dengan subtitle apa, dan apabila di tengah-tengah menonton film tidak sengaja berhenti atau browser ke close, user akan mendapat opsi untuk melanjutkan dari waktu terakhir film tersebut diputar.

Situs ini menyediakan film dalam format mp4 dan film dapat di-download secara langsung apabila laptop terinstall software internet download manager (yaitu ketika film terputar, maka secara otomatis fitur IDM akan langsung mendeteksi film tersebut sebagai objek download-layaknya ketika kita memutar video di youtube, dan kualitas video yang didownload menyesuaikan dengan kualitas video yang kita pilih sebelum kita play film). Jika user tidak menginstall software IDM di pc/laptopnya, user tetap bisa mendownload secara manual yaitu dengan klik tab "Download" kemudian ikuti instruksi berikutnya pada platform. Prosedur ini memungkinkan film yang sedang diputar untuk di-copy ke akun googledrive user, kemudian barulah user dapat men-download film secara manual lewat google drive.

IndoXXI sangat memperhatikan update kontennya. Proses pengupdatean konten (biasanya film) bahkan sudah dimulai sejak film tersebut masih tayang di bioskop. Namun, kualitas yang ditawarkan juga masih dengan kualitas bajakan rendah. Perbedaan waktu tayang kerap menyebabkan film produksi asing yang "belum tayang" di bioskop Indonesia biasanya malah sudah tersedia di situs ini. Film Indonesia di sini juga sangat lengkap dan cukup update. IndoXXI menciptakan beberapa kolom yang menjadi wadah kategorisasi film. Ada banyak bentuk kategorisasi yang disediakan, mulai dari berdasarkan genre, berdasarkan macam (film/serial TV/anime), berdasarkan box office/ tidaknya, top 500 movie versi mereka, dan bahkan ada kolom "Bioskop21" yang secara khusus memang mengelompokkan film2 (mayoritas Hollywood) dengan rating IMdB $7 \mathrm{ke}$ 
atas. Perlu dicatat, bahwa dalam situs ini terdapat banyak sekali iklan seperti iklan poker, judi online, dan sebagainya.

Sedikit berbeda dengan indoXXI, icinema3satu adalah salah satu situs download film,anime, dan TV series di Indonesia. icinema3satu didirikan sekitar awal bulan Mei2009. Berawal dari kekecewaan terhadap salah satu forum yang tidak mengijinkan anggotanya untuk men-sharing file film yang menggunakan link idws (indowebster). Dari situlah muncul ide membuat blog pribadi untuk men-sharing film khususnya yang menggunakan link idws. Mulanya, icinema3satu bernama Cinema3satu dan masih berupa blog, bukan situs web. Cinema3satu mengalami beberapa kali masa keterpurukan, seperti situs yang diblokir atau di-hack. Setelah berulangkali tertimpa masalah demikian, akhirnya Cinema3satu berubah nama menjadi icinema3satu.

Icinema3satu memiliki fitur live streaming. Kualitas film live streaming sesuai dengan kualitas film yg dapat didownload. Situs ini menyediakan kualitas film 720p hingga 1080p. Link download film dan subtitle pada situs ini disajikan secara terpisah. Icinema3satu membagi tiga kategori konten, yaitu film ,anime, dan serial TV. Untuk film, situs ini membaginya ke dalam beberapa kategori lagi, yaitu: Genre, Asian movies, Years, Rating 7-10, 3D (film 3D), dan 1080p. Selain itu, situs ini juga memudahkan user dengan adanya fitur index berdasarkan huruf awal judul, abjad A-Z dan angka. Seperti halnya indoXXI, Icinema3satu juga memuat iklan. Ada berbagai iklan seperti iklan senapan angin, jasa titip barang dari LN, poker, game murah (game bajakan), Aldot Reload (server pulsa dan paket data), dan lain-lain. Iklan diposisikan secara rapih sehingga tidak muncul berantakan.

Berbeda dengan platform tersebut di atas, SevenTorrent merupakan situs download film/TV Series berbasis torrent. Torrent tersebut merujuk pada sistem $\mathrm{p} 2 \mathrm{p}$ (atau sistem berbagai peer to peer). SevenTorrenttidak menyediakan fitur streaming, hanya khusus untuk download. Situs ini menyediakan berbagai macam format video yang dapat di-download seperti format AVI, MKV, dan MP4 serta menyediakan film/ series dengan resolusi video 720p dan 1080p. Bahkan film/series yang disediakan juga ada dalam format asli (dolby, dengan size yang sangat besar) dan juga 3D (hanya pada film tertentu). Semua film/series hanya bisa didownlaod via torrent downloader, yaitu dengan mendownload file torrent, kemudian mendownload lagi file asli dengan memasukkan file torrent ke dalam software torrent downloader. Situs ini menampilkan iklan, termasuk iklan pop up (yang tiba-tiba membuat browser kita membuka laman baru) dan juga iklan-iklan berupa artikel, seperti "cara menguras lemak", dll.

\section{Praktik Partisipan}

Perspektif partisipan merupakan hal penting yang ingin dipahami dalam penelitian ini. Berdasarkan kebutuhan tersebut, penelitian menyelenggarakan focus group discussion dengan enam orang yang telah lama terlibat dalam praktik mengakses film ataupun program TV melalui situs bajakan. Ada enam orang yang menjadi partisipan dengan jangkauan umur dari 17-22 tahun. Seluruh peserta berstatus sebagai mahasiswa dari berbagai bidang. Latar belakang mahasiswa atau anak muda di sini lebih merupakan kebutuhan praktis, tanpa bermaksud menegaskan bahwa praktik ini hanyalah praktik untuk kaum muda dengan pendidikan tinggi. Fokus diskusi dapat dibagi ke dalam delapan topik yang intens dibicarakan, mulai dari pengalaman hingga pandangan partisipan pada konteks praktik ilegalnya.

a. Pengalaman Mengakses Situs
Bajakan
Sebagian besar partisipan
mengaku telah melakukan praktik


mengakses situs bajakan sejak 3-5 tahun sebelumnya. Ada berbagai jenis film/program TV yang mereka akses. Fakhin (19 tahun) kerap mengakses situs bajakan untuk menonton filmfilm berkualitas (khususnya film yangmendapatkan nominasi Oscar) melalui situs seperti primewire.ac dan movie123. Alasannya karena dalam situs-situs tersebut ditawarkan kualitas HD dan update yang cepat meski tidak dengan subtitle indonesia. Selain itu, ia juga kerap menonton anime (serial animasi Jepang) melalui masterani. me. Durasi anime yang singkat dirasa tepat untuk menjadi tontonan selingan. Anime juga merupakan jenis program TV/film yang digemari oleh Bangkit (22). la biasa mengakses melalui animeindo. id dengan subtitle indonesia.

Diko (20) mulai mengenal situs penyedia film/program TV bajakan sejak 2014. Awalnya ia mengenak sebuah situs forum sharing film IDFL (Indowebster). Saat itu ia aktif mengikuti acara forum tersebut, seperti gathering. Dalam situs IDFL, disediakan link download yang biasanya langsung mengunduh data ke Google Drive pengguna. Meski saat ini Diko mengaku tidak begitu aktif dalam forum tersebut, namun menurutnya forum tersebut masih aktif hingga sekarang. Berbeda dengan Diko, Tashya (17) memilih situs dramanice dan myasiantv sebagai tempat mengakses tontonannya. Situs ini sendiri lebih menyediakan program TV/film dari Asia Timur, khususnya Drama Korea yang digemari Tashya.

Lain situs, lain pula fiturnya. Diko menjelaskan untuk IDFL memiliki lima domain. Yang paling sering dipakai adalah idfl.me, domain lainnya dijadikan cadangan jika "server down". Film/program TV dapat diakses dengan memilih thread terlebih dahulu, misal thread film barat atau asia. Ada pula thread subtitle (dengan kontribusi subber populer: lebahganteng \& peinakatsuki). IDFL menggunakan sistem forum tertutup, sehingga setiap member perlu mendaftar terlebih dahulu. Pada umumnya IDFL tidak menarik biaya, meski ada keanggotaan khusus dengan biaya per bulan (keuntungan khusus misalnya dapat me-request film). IDFL juga memiliki chatbox sehingga sesama member bisa berkomunikasi. Keuntungan IDFL sendiri kemungkinan diperoleh dari iklan, meski iklan di sini tidak kerap muncul sehingga membuat nyaman member. IDFL yang dikembangkan oleh orang Indonesia ini menggunakan tampilan bahasa Indonesia.

Jika platform sirkulasi legal mendapatkan keuntungan dengan kontrak resmi dengan produsen konten, situs bajakan memiliki cara sendiri dalam memperoleh keuntungannya. Misalnya dengan memberikan ruang iklan. Partisipan memiliki cara pandang beragam tentang bagaimana situs bajakan memperoleh keuntungan dari iklan ini. IndoXXI atau LK21 merupakan salah satu web yang dikenal menampilkan banyak iklan secara kurang teratur. Ari menuturkan bagaimana di LK21 banyak iklan pop up, iklan yang muncul dengan membuka tab baru ketika mengklik sesuatu. Menurut Fakhin, iklan dalam LK21 antar lain judi online, judi togel, dan konten 18+. Untuk platform IDFL, Diko bercerita bagaimana iklan akan muncul untuk member biasa. Sedangkan iklan tidak akan muncul untuk member khusus.

\section{b. Download atau streaming?}

Seperti dipaparkan sebelumnya, sirkulasi film dan program TV melalui internet menawarkan dua basis akses, yakni: download dan streaming. Keduanya sama-sama mengharuskan akses internet yang cukup. Bedanya dengan download, pengguna dapat menyimpan data dan mengaksesnya di waktu lain. Sedangkan dengan streaming, data hanya dapat diakses di waktu tersebut. Streaming mengharuskan akses internet yang stabil jika tidak ingin terjadi buffering 
saat menonton. Namun, tidak seperti download, streaming tidak mengharuskan pengguna memiliki penyimpan data (harddisk/memory). Perbedaan cara akses download atau streaming ini menjadi pilihan partisipan dengan berbagai pertimbangannya.

Diko dan dua partisipan lain, Dika (21) dan Ari (21), lebih senang melakukan download. Diko lebih mengutamakan menyimpan film di harddisknya. Hal ini juga selaras dengan bagaimana link yang ia dapat dari platform IDFL. Dika memilih download dengan alasan koleksi. la mengikuti serial televisi yang keluar per minggu, sehingga baginya penting untuk menyimpan episodeepisode terdahulu serial yang ia ikuti. Tidak jarang ia menghapus koleksi serialnya jika dirasa tidak lagi akan ditonton. Sementara Ari mengaku lebih sering mendownload film atau program TV yang berkualitas bagus dengan menggunakan wifi di kost. Jika tidak menggunakan wifi, ia kerap mengakses menggunakan streaming.

Streaming menjadi pilihan partisipan lain. Fakhin misalnya lebih sering melakukan streaming karena menggunakan koneksi wifi yang ada di berbagai tempat (kampus misalnya). la enggan men-download karena memakan waktu. Selain itu, streaming juga kerap ia lakukan melalui ponsel. la juga kerap menonton film secara streaming bersama keluarga menggunakan laptop yang disambungkan ke pesawat TV. Fakhin tidak terlalu mempermasalahkan kualitas gambar selama cukup jelas untuk dilihat. Streaming sendiri umumnya menyesuaikan kualitas gambar dengan kecapatan koneksi internet. Selaras dengan Fakhin, Tashya memilih streaming. Alasan tempat penyimpanan data yang terbatas menjadi salah satu alasan pentingnya.

c. Akses di luar Situs Bajakan

Pertanyaan sederhana yang didiskusikan dengan partisipan: apakah para pengakses situs bajakan ini juga mengakses tontonan secara legal? Film misalnya dalam jalur legal mainstream disirkulasikan melalui bioskop atau DVD/Blu-Ray. Beberapa partisipan mengaku masih sesekali menonton di bioskop, khusus film-film yang dirasa penting. Salah satu partisipan, Tashya, masih membeli DVD karena keluarga juga suka menonton melalui DVD player. Di tengah perkembangan sirkulasi digital, sirkulasi dalam bentuk DVD atau Blu-Ray kemungkinan besar lebih identik pada pengguna dengan usia yang tidak muda lagi.

Sementara di era digital, jalur legal juga merambah pada platform online.. Di samping itu, ia juga pernah mengakses platform HOOO. Namun platform tersebut dirasa kurang lengkap, misalnya tidak memuat anime. Selain itu, Fakhin juga pernah menggunakan TV kabel dengan servis Indovision. Platform online legal lain yang didiskusikan adalah platform iflix dan viki. Bangkit bercerita pernah mengakses iflix di ponsel. Namun, ia merasa update film baru di iflix kurang cepat. Sementara Dika pernah menggunakan iflix karena ada promo. Tashya pernah menggunakan platform Viki. Menurutnya isinya lebih banyak drama dari negara Korea, Cina, dan Thailand.

Selain akses secara legal, para partisipan juga turut aktif melakukan sirkulasi dengan sistem file-sharing. Ari mengaku pernah juga mengopi film/program TV dari warnet. la meninggalkan warnet karena merasa kategorisasi di warnet tidak seseerhana dulu. Sementara Fakhin justru lebih sering mengopi dari rekannya yang mengopi film di warnet. Bagi Diko, kualitas film/program TV yang didapat via warnet tidak pasti sebagus kualitas jika ia men-download sendiri. la sendiri saat ini jarang berbagi data dengan teman. Apa yang ia download lebih untuk konsumsi pribadi. 


\section{d. Memaknai Legalitas Praktik}

Sirkulasi digital via platform yang disebut sebagai "situs bajakan" dalam penelitian ini, dalam perspektif hukum dapat dikatakan sebagai praktik ilegal. Menjadi pertanyaan, apakah partisipan sendiri memaknai praktik mereka sebagai suatu hal yang melanggar hukum? Dalam konteks film, Diko memandang praktik downloadnya sebagai pelengkap praktik mengakses film di bioskop. Tujuannya lebih ke aspek koleksi. Sementara dalam konteks program TV, praktik download untuk memenuhi kebutuhan akan program/ serial TV yang memang tidak disiarkan di TV lokal. Diko sendiri belum memiliki bayangan apakah ke depannya akan meninggalkan praktik ini dan beralih ke cara-cara akses yang lebih legal.

Fakhin memiliki pandangan yang berbeda dengan Diko. Menurutnya, produsen film atau program TV yang ia tonton sudah memiliki banyak keuntungan dari jalur legal. Dengan banyak penonton bioskop suatu film, ia merasa praktik download bukan merupakan masalah besar bagi produsen. Di sisi lain ia merasa pastilah tidak menyenangkan berada dalam posisi para produsen yang karyanya dibajak. Tapi serba instannya sirkulasi produk media mau tidak mau merupakan hal yang harus dihadapi pada masa kini. Tahsya menanggapi hal ini dengan melihat bahwa ini semua adalah masalah kebutuhan dan kemampuan. Sepakat dengan pendapat Diko di atas, jika ke depan ia telah memiliki banyak uang, mungkin ia tidak akan meninggalkan praktik ilegal ini.

\section{Streaming \& Download dalam Persepktif Pembajakan Digital}

Salah satu definisi umum mengenai pembajakan digital atau digital piracy adalah praktik mengopi (to-copy) dan menjual secara ilegal produk film, musik, software komputer digital, dan media digital lainnya Seiring perkembangan teknologi, praktik mengopi ini menjadi semakin kompleks. Praktik download dan streaming dapat dikatakan sebagai bentuk baru kompleksitas penyalinan media digital. Download secara sederhana dapat dilihat sebagai tindak lanjut dari berbagi data via internet. Streaming dapat diakatakan sebagai praktik yang lebih kompleks, karena dalam streaming tidak ada penyalinan data. Namun, dalam streaming konten diputar dan ditonton oleh pengguna, sehingga kontenlah yang tersalin, namun tanpa meninggalkan jejak data salinan.

Paparan data dalam observasi platform di atas menunjukkan bagaimana saat ini arus industri film dan televisi mencoba merambah dunia digital, dengan berbagai strategi menghadapi pembajakan digital. Sistem streaming member berlangganan misalnya merupakan salah satu caranya. Dalam sistem ini, hanya penonton yang telah membayar saja yang bisa menonton, itupun dalam tempo waktu terbatas. Sistem ini diasumsikan membuat pengguna tidak bisa berbagi tontonan dengan orang lain yang tidak menjadi member. Beberapa platform legal menyediakan fitur download, tapi hanya dengan aplikasi tertentu. Dalam sistem download ini, pengguna diberi kemudahan untuk mengakses media, namun sulit untuk mensirkulasikan media ke orang lain.

Platform sirkulasi online ilegal, dalam hal ini situs film/program TV bajakan, adalah sebuah konsekuensi dari sirkulasi online. Seperti halnya yang dialami oleh industri media hiburan berbasis VCD atau DVD, sistem distribusi online juga mendapatkan tantangan dari praktik pembajakan digital. Kelly Hu (2005) yang meneliti konsumsi drama TV Jepang di Cina menemukan bagaimana fans drama TV Jepang di Cina merupakan pihak yang bergerilya secara otonom, mengembangkan jejaring teknologi digital yang minim biaya, serta menentang hierarki distribusi resmi. Dalam konteks ini, kemunculan platform online dapat dilihat sebagai bentuk negosiasi yang disambut baik oleh para pelaku praktik download dan streaming. 
Meski demikian, terlalu naif untuk melihat kelahiran platform online ilegal sebagai hal yang politis belaka. Lahirnya situs-situs bajakan mau tidak mau tidak lepas dari sistem ekonomi yang coba dibangun oleh produsen platform, terutama melalui adanya iklan dalam situs. Sejalan dengan sifat situs yang cenderung ilegal, iklan yang dipasang pun produk atau jasa yang cenderung ilegal, seperti: judi online, jual senapan angin, hingga konten 18+. Salah satu platform ilegal, Indowebster, mencoba mencari pemasukan ekonomi dari cara member, serupa dengan yang dilakukan oleh platform legal. Tentunya dengan memberi tawaran spesial pada member, misal dapat melakukan request judul film/ program TV.

Dengan membaca praktik yang dilakukan partisipan, makna "ilegal" dalam praktik download dan streaming menjadi perlu dikaji ulang. Meninjau argumen Lessig, jika faktor kunci dari "pembajakan" yang mau diberantas oleh hukum adalah penggunaan yang "merampok" keuntungan si pencipta (2004: 81), ini berarti perlu dipastikan apakah dan seberapa banyak sistem berbagi dalam budaya mengopi menimbulkan kerugian. Misalnya Lessig memiliki poin bahwa praktik pembajakan (berbagi data) bisa dilakukan untuk mendapatkan akses konten berhak cipta yang sudah tidak lagi dijual. Serupa tak sama, terdapat partisipan yang mengakses program TV negara lain yang memang tidak tayang di Indonesia.

Menghakimi sebuah pembajakan sebagai aktivitas ilegal yang melanggar hukum adalah sebuah perspektif sempit yang dibangun dari perspektif industri dengan logika distribusi konvensional. Perspektif ini menutup mata dari adanya negosiasi pelaku pembajakan yang terus berkembang seiring perkembangan ekonomi dan teknologi distribusi media. Salah satu partisipan misalnya dengan tegas memiliki pandangan bahwa produsen film atau program TV yang ia tonton sudah memiliki banyak keuntungan dari jalur legal. Dengan banyak penonton bioskop suatu film, ia merasa praktik download bukan merupakan masalah besar bagi produsen.

Praktik download dan streaming dengan ini perlu dipahami secara lebih luas, tidak hanya dari perspektif produsen. Dari praktik partisipan atau pelaku, setidaknya dapat dicatat beberapa aspek yang melahirkan praktik ini: keintiman pelaku dengan teknologi digital baik yang legal maupun ilegal, semangat mengakses tontonan dengan efisien dan semurah mungkin, serta pertimbangan-pertimbangan teknis seperti perihal subtitle dan kualitas video. Sifat generasi ini tak bisa dipungkiri menjadi tantangan industri film/program TV di tengah maraknya sirkulasi digital. Cara alternatif perlu dikembangkan jika tidak ingin industri mati, misalnya dengan produksi berbasis grant, sponsored, atau crowd-funding. Cara-cara ini tentunya harus terus berkembang seiring dinamika teknologi yang memungkinkan berbagai cara audiens mengakses media digital.

\section{E. Kesimpulan}

Dari penelitian yang dilakukan, praktik download dan streaming dapat dikatakan sebagai bentuk baru kompleksitas penyalinan media digital. Download secara sederhana dapat dilihat sebagaitindak lanjut dari berbagi data via internet. Streaming dapat diakatakan sebagai praktik yang lebih kompleks, karena dalam streaming tidak ada penyalinan data. Namun, dalam streaming konten diputar dan ditonton oleh pengguna, sehingga kontenlah yang tersalin, namun tanpa meninggalkan jejak data salinan. Industri film dan televisi mencoba merambah dunia digital, dengan berbagai strategi menghadapi pembajakan digital. Sistem streaming member berlangganan misalnya merupakan salah satu caranya. Beberapa platform legal menyediakan fitur download, tapi hanya dengan aplikasi tertentu. Dalam sistem download ini, pengguna diberi kemudahan untuk mengakses media, namun sulit untuk mensirkulasikan media ke orang lain.

Platform sirkulasi online ilegal, dalam hal ini situs film/program TV bajakan, 
adalah sebuah konsekuensi dari sirkulasi online. Kemunculan platform online dapat dilihat sebagai bentuk negosiasi yang disambut baik oleh para pelaku praktik download dan streaming. Lahirnya situssitus bajakan mau tidak mau tidak lepas dari sistem ekonomi yang coba dibangun oleh produsen platform, terutama melalui adanya iklan dalam situs. Sejalan dengan sifat situs yang cenderung ilegal, iklan yang dipasang pun produk atau jasa yang cenderung ilegal, seperti: judi online, jual senapan angin, hingga konten $18+$. Praktik download dan streaming dengan ini perlu dipahami secara lebih luas, tidak hanya dari perspektif produsen. Dari praktik partisipan atau pelaku, setidaknya dapat dicatat beberapa aspek yang melahirkan praktik ini: keintiman pelaku dengan teknologi digital baik yang legal maupun ilegal, semangat mengakses tontonan dengan efisien dan semurah mungkin, serta pertimbanganpertimbangan teknis seperti perihal subtitle dan kualitas video. Untuk mengembangkan penelitian ini lebih lanjut, peneliti menyadari bahwa riset ini masih berada dalam fase awal, yaitu fase mengenal dinamika umum platform online serta praktik mengakses situs bajakan. Informan dalam riset ini sangat terbatas yaitu enam pelaku praktik download dan streaming, sehingga hasil yang dipaparkan sangat mungkin bias terhadap perspektif dari produsen konten, pemiliki situs, serta pelaku lain. Oleh karena itu penting untuk mengembangkan riset ini lebih lanjut dengan metode pencarian data yang lebih variatif dan informan yang lebih beragam.

\section{DAFTAR PUSTAKA}

Anshari, Irham N. 2017. "Memahami Ulang Pembajakan Media Digital" dalam Sulhan, M \& Wijayanti, Y. T. (ed.) Dinamika Komunikasi: Konsep dan Konteks di Beragam Bidang Kehidupan. Yogyakarta: Aspikom Press.

Hu, Kelly. 2005. "The power of circulation: digital technologies and the online Chinese fans of Japanese TV drama" dalam Inter-Asia Cultural Studies, Volume 6, Number 2.

Jenner, Mareike. 2016. "Is this TVIV? On Netflix, TVIII and binge-watching" dalam New Media \& Society Vol. 18(2) 257-273.

Jenkins, Henry, Sam Ford, \& Joshua Green. 2013. Spreadable Media. New York \& London; New York University Press.

Jung, Sun \& Doobo Shim. 2014. "Social distribution: K-pop fan practices in Indonesia and the 'Gangnam Style' phenomenon" dalam International Journal of Cultural Studies Vol. $17(5)$ 485-501.

Kim, Eun-mee \& Sora Park. 2008. "Distributing TV dramas in the digital environtment: a Korean case" dalam Asian Journal of Communication Vol. 18, No. 2, June 2008, 137 154.

Klinger, Barbara. 2006. Beyond the Multiplex. Los Angeles: University of California Press.

Lessig, Lawrence. 2004. Free culture: How Big Media Uses Technology and the Law to Lock Down Culture and Control Creativity. New York: Penguin Press.

Lindlof, T. R. 2002. Qualitative Communication Research Methods. Thousand Oaks, CA: Sage.

MacNeill, Kate. 2016. "Torrenting Game of Thrones: So wrong and yet so right" dalam Convergence: The International Journal of Research into New Media Technologies $1-18$.

Newman, Michael Z. 2012. "Free TV: File-Sharing and the Value of Television" dalam Television and New Media 13(6) 463-479. 
Pradehsa, Nadi Tirta. 2015. "22 situs diduga pembajak film diblokir Kemenkominfo" dalam CNN Indonesia (https://www.cnnindonesia.com/hiburan/20150819083659-22073041/22-situs-diduga-pembajak-film-diblokir-kemenkominfo).

Strangelove, Michael. 2015. Post-TV. Toronto: University Toronto Press.

Wimmer, R. D. \& Dominick J. R. 2010. Mass Media Research: An Introduction. Boston: Wadsworth Publishing.

Yin, R. 2003. Case study research (3rd ed.). Newbury Park, CA: Sage Publications. 